УДК $81 ' 2$

DOI: 10.33184/YVDK-2021-04-30.26

P.Р. Исхакова (к.фил.н., преп. МКСО, г. Магнитогорск), Г.Н. Салимова (ст. преп. СФ БашГУ, г. Стерлитамак)

\title{
РОЛЬ СТИЛИСТИЧЕСКИХ СРЕДСТВ В ВЫРАЖЕНИИ ПРОБЛЕМ ЭКОЛОГИЧЕСКОГО ХАРАКТЕРА В БАШКИРСКИХ ПОЭТИЧЕСКИХ ТЕКСТАХ
}

В настоящей статье стилистические средства башкирского языка рассматриваются на материале поэтических текстов с точки зрения их роли в выражении экологических проблем региона. Поэтические тексты, отличающиеся своей образностью и своебразной конструкичей, дают возможность автору донести до читателя субъективное отношение к тому или иному явлению или событию.

Ключевые слова: стилистические средства, поэтический текст, образность, автор, реичииент, экологические проблемы.

This article considersthe the stylistic means of the Bashkir in poetic texts from the point of view of their role in expressing the environmental problems of the region. Poetic texts, distinguished by their imagery and peculiar construction, allow the author to convey to the reader a subjective attitude to a particular phenomenon or event.

Keywords: stylistic means, poetic text, imagery, author, recipient, environmental problems.

Языковая природа поэтического текста своеобразна. Прежде всего, следует отметить, что поэтический текст - это результат сложной речемыслительной деятельности, отличающийся от художественных текстов прозаического характера своей формой, краткостью изложения, эмоциональностью, организованностью языка. С точки зрения Г.О. Винокура, в поэтических текстах «не 
только оживляется все механическое, но и узаконивается все произвольное» [Винокур 1959: 253].

Всестороннее исследование особенностей поэтических текстов мы находим у К.Э. Штайна, по мнению которого, стихотворное произведение - это многогранное, сложное языковое явление, характеризующееся сплетением разных элементов языка, особой (структурно закрытой) формой, гармоничностью, внутренними законами, возможностью внутренней саморегуляции, эмоциональной окрашенностью, способностью произвести на читателя глубокое впечатление [Штайн 2006: 42].

Обобщая все вышеперечисленные свойства поэтического текста, можно утверждать, что его характерными особенностями являются своеобразная конструкция, ритм, рифма и образность. Образность может быть достигнута только благодаря умелому использованию автором стилистических средств языка. Именно язык поэзии дает возможность автору выразить субъективное отношение к тому или иному явлению, донести до сознания реципиента определенную идею, оценку фактов действительности, изменить картину мира реципиента посредством выразительных средств.

Данная статья посвящена стилистическому анализу поэтических текстов современных башкирских авторов, освещающих экологические проблемы региона. Как известно, что в художественных текстах отражаются образ жизни, менталитет, настроение, эмоциональное состояние общества. На настоящем этапе одной из наиболее насущных проблем башкирского народа является проблема сохранения родной природы. Тревога, беспокойство, отчаяние народа ощущаются в стихотворениях современных авторов, которые пытаются донести до властей через свои стихи, что природа - это наша среда обитания, «сук, на котором мы сидим».

Одним из наиболее часто встречающихся стилистических средств в поэтических текстах является риторический вопрос. Это очевидно, поскольку именно в процессе поиска ответов на те или иные насущные вопросы рождается стихотворение:

Кемдәр хужа икән без̧зен ерга,

Без̧зец күлдәр, йылга, таузарва!? (Римма Буранбаева) 
В данном фрагменте автор обращается к читателям с целью заставить их задуматься о том, что наши родные земли находятся в руках чужих людей.

Как известно, минувший год запомнился жителям не только республики Башкортостан, но и всей страны резонансным скандалом вокруг шихана Куштау. Появился целый ряд статей и стихов, освещающих данную проблему. Цель авторов «достучаться» до вышестоящих органов, что наше поколение обязано сохранить природу для будущих поколений:

Куш йөрәкле бульу кәрәкмелер

Куштау яклап һүзең әйтергә!? (Гүзәл Ситдикова)

Посредством риторического вопроса автор обращается к знатным представителям своего народа, призывая их не оставаться в стороне, когда на кону стоит вопрос о сохранении природных реликвий нашей республики.

В следующем отрывке из стихотворения автор выражает свои эмоции, свое отношение к происходящему посредством эпитета:

Бары тама күзззан кайнар йәштәр,

Башка һүзем дә юж язырлык! (Римма Буранбаева)

Эпитеты способны не только придать речи выразительность и поэтическую яркость, но и вызвать у реципиента сильные эмоции:

Ер кыртышыы күптән актарылган,

Үсер урын тапмай сал кылган. (Әкрәм Кәйепколов)

Присутствие здесь эпитета не случайно: седой ковыль ассоциируется со старейшинами народа, обеспокоенными экологической ситуацией в стране.

Авторы стихотворений также прибегают к стилистическому приему аллюзии с целью придать достоверность и историческую точность своему произведению:

Тик бөгөн дә Катил гәскәрзәре

Сыzам тиеп тора алышка. (Лариса Абдуллина)

Здесь упоминается жестокий царь из эпоса «Урал батыр».

Сравнение - одно из самых эффективных языковых средств, позволяющих автору выразить свое отношение к событиям и явлениям эксплицитным образом, не усложняя реципиенту акт восприятия:

Минең халкым кемдәргәлер

Казина hьммак. (Лариса Абдуллина) 
Суть сравнения здесь заключается в том, что, по мнению автора, наш край служит для чиновников и олигархов источником богатства. По этой причине уничтожаются леса, загрязняются воздух и вода, истощается запас полезных ископаемых.

Таузарыңдан сокор кала бара,

Әйтерһең дә зур бер кәберлек... (Гүзәл Ситдикова)

В анализируемом примере уничтоженная природа сравнивается с могилой.

Очень часто поэты прибегают к приему олицетворения в своих произведениях. В следующем фрагменте олицетворение дает возможность автору обратиться к читателю от имени самой горы, находящейся под угрозой исчезновения:

Фани доньяларза эшем бөткәс,

Үтер күперзорем бульр кыл.

Шул савында Куштау

Әйз утһен. Минең ульым был. (Насип һакмаров)

Подобный пример мы находим в стихотворении-призыве, также посвященном проблеме сохранения горы Куштау:

Телгә килде Куштау: “Эй, башкортом,

Үз̆-Үзенц кәбер каз̆ымиа!

Бөгөн каззван сокор етер

Eте быуын ул һәм кыззыңц!"” (Тәңкәбикә)

Здесь автор обращается к народу с просьбой о прекращении жестоких деяний по отношению к природе, ибо их последствия погубят жизнь будущих поколений.

Загрязнение водоемов - еще одна насущная проблема, которую поднимают писатели и поэты в своих произведениях:

Һакмар ава, Үзе бойок,

- һаумы, Һакмар, арыумы? ...

Һакмар дйтте, һинең һүзен

Минең өсөн дарыумы? (Әкрәм Кәйепколов)

В данном фрагменте автор вступает в диалог с рекой, желая донести до аудитории, что природа - живой организм, а мы - ее дитя. Мы должны заботиться о ней, жить с ней в гармонии, чтобы она продолжала нам служить средой обитания.

Невозможно представить поэзию без повторов. Стилистический прием повтора позволяет автору не только сохранить стиль, рифму и ритм поэтического текста, но и 
обратить внимание читателя на определенные факты, оказать на него более глубокое эмоциональное воздействие:

Ошо күктәр, ошо ерзәр-

Oшо haya - булван бәрәкәт. (Гөлнара Хәлфетдинова)

С помощью приема повтора здесь поэтесса призывает народ к сохранению природного богатства - родных земель, чистоту воздуха.

Метафора - стилистический прием, способный имплицитно передать отношение автора к негативным явлениям или событиям. В следующем примере автор описывает действия властей, направленные на уничтожение лесов и священной горы башкирского народа, с помощью приема метафоры:

Кем һуң беззен урмандарзы кыра,

Кем Куштаузы канга батырган. (Тәңкәбикә)

Метонимия способствует сокращению, сжатию речи. Она дает возможность автору передать больше информации, используя меньше языковых средств, что является одним из наиболее важных условий поэтического текста:

Мәскәу туймай, шунһыз булмай тиеп,

Сизәм ерзәр күптән актарылган. (Әкрәм Кәйепколов)

Здесь название города представляет не столько жителей данного города, сколько столичных чиновников и олигархов, которые никак не могут «обуздать» свою алчность и продолжают грабить природные богатства.

Как показывает анализ языкового материала, авторы поэтических текстов используют огромное разнообразие выразительных средств башкирского языка, чтобы добиться желаемого результата, заключающегося в попытке объяснить властям и своему народу о необходимости относиться к родной природе бережно, ведь это наша собственная среда обитания.

\section{ЛИТЕРАТУРА}

1. Винокур Г.О. Избранные работы по русскому языку. - М., 1959. - C. 253.

2. Штайн К.Э. Гармония поэтического текста. - Ставрополь, 2006. - C. 42.

(c) Исхакова Р.Р., Салимова Г.Н., 2021 г. 